\title{
World Trade Organization
}

Economic Research and Statistics Division

This paper appears in the WTO working paper series as commissioned background analysis

for the World Trade Report 2010 on "Trade in Natural Resources: Challenges in Global Governance"

\section{The relation between international trade and freshwater scarcity}

\author{
Arjen Y. Hoekstra
}

University of Twente, the Netherland

Manuscript date: January 2010

Disclaimer: This is a working paper, and hence it represents research in progress. This paper represents the opinions of the author, and is the product of professional research. It is not meant to represent the position or opinions of the WTO or its Members, nor the official position of any staff members. Any errors are the fault of the author. Copies of working papers can be requested from the divisional secretariat by writing to: Economic Research and Statistics Division, World Trade Organization, Rue de Lausanne 154, CH 1211 Geneva 21, Switzerland. Please request papers by number and title. 


\title{
The relation between international trade and freshwater scarcity
}

\author{
Arjen Y. Hoekstra \\ Department of Water Engineering and Management \\ University of Twente \\ P.O. Box 217, 7500 AE Enschede, the Netherlands \\ Phone +31 534893880 \\ E-mail a.y.hoekstra@utwente.nl
}

WTO Working Paper / January 2010

\section{Summary}

It is becoming increasingly important to put freshwater issues in a global context. Local water depletion and pollution are often closely tied to the structure of the global economy. With increasing trade between nations and continents, water is more frequently used to produce exported goods. International trade in commodities implies long-distance transfers of water in virtual form, where virtual water is understood as the volume of water that has been used to produce a commodity and that is thus virtually embedded in it. Knowledge about the virtualwater flows entering and leaving a country can cast a completely new light on the actual water scarcity of a country. For example, Jordan imports about 5 to 7 billion $\mathrm{m}^{3}$ of virtual water per year, which is in sharp contrast with the 1 billion $\mathrm{m}^{3}$ of water withdrawn annually from domestic water sources. This means that people in Jordan apparently survive owing to the import of water-intensive commodities from elsewhere, for example the USA.

This report reviews current knowledge with respect to four questions: What is the effect of international trade on domestic water resources? What is the effect of water availability on international trade? Can international trade increase global water-use efficiency? And finally, what type of international trade rules would promote a more wise use of water worldwide?

It is shown that import of water-intensive commodities reduces national water demand, which is attractive for water-scarce countries like in the Middle East and North Africa. Export of water-intensive commodities, on the contrary, raises national water demand and thus enhances national water scarcity. This happens for instance in the USA and Australia. Trade patterns thus influence patterns of water use and scarcity. Reversely, spatial differences in water scarcity do not seem to have a strong influence on trade patterns. The reason is that water is generally grossly underpriced. Water scarcity appears to affect trade patterns only in cases where absolute water shortage forces water-scarce countries to import water-intensive products, because they simply cannot be produced domestically. The report shows that currently international trade reduces global water use in agriculture by $5 \%$, which is the result of the fact that water-intensive commodities are traded, on average, from countries with high to countries with low water productivity. Global water-use efficiency can be increased by including water scarcity as a factor into trade decisions. However, increased trade in water- 
intensive products possibly has a number of downsides, like for instance increased water dependencies.

Currently there is an imbalance between international trade agreements and international agreements on sustainable water use, because the former are strong and the latter weak. Most relevant is that internationally binding agreements on sustainable water use do actually not exist. There are no international agreements of the type that have the strength to restrict trade in cases where it negatively affects local water systems. It is argued that fair international trade rules should include a provision that enables consumers, through their government, to raise trade barriers against products that are kept responsible for harmful effects on water systems and indirectly on the ecosystems or communities that depend on those water systems. The report identifies several mechanisms to better ensure that trade and sustainable water use go hand in hand: product transparency, e.g. through a water label, an International Water Pricing Protocol and an International Water-Footprint Permit System.

International agreements on the liberalization of trade in agricultural products - as being negotiated in WTO's ongoing Doha Development Round - should include provisions that promote sustainable water use in agriculture. As yet it is unclear how such provisions could look like, since the WTO explicitly refrains from making environmental agreements. An imbalance in global regulations of trade will be created as soon as free trade agreements are effective while sustainable-product and sustainable-water-use agreements to constrain international trade are not yet existent. This is a serious risk, since no international agreements on sustainable water use or sustainable products do exist or are being prepared.

Keywords: Water resources management, International trade, Virtual-water trade, Water footprint, Water-use efficiency, Product transparency, Water pricing, Water labelling. 


\section{Introduction}

The recent past has shown a growing interest from both trade and water experts in the relation between international trade and freshwater scarcity. Until the recent past, it has not been very common for water sector specialists to look at the relation between water use in a region and import into or export from this region. Traditionally, in their view, water demand in an area is simply a function of the amount and sort of water users in that area. At the same time, economists do generally not bother much about the implications of international trade for the water sector. The reason is that water inputs usually hardly contribute to the overall price of traded commodities. This seems to justify the conclusion that water cannot be a significant factor influencing production and trade patterns. The fact that water inputs are often heavily subsidized by national governments is hereby ignored. Trade specialists also tend to forget that external effects of water use can be very significant, but are never included in the price of water and that no country charges a scarcity rent for water inputs even though water is sometimes very scarce. When merely looking at the prices of traded commodities one will indeed get the impression that water scarcity cannot be a driving force of or limiting factor to international trade.

Water is usually not regarded as a global resource. Whereas in most countries the energy sector has an obvious international component, this is different for the water sector. The international component of water is recognized in the case of trans-boundary rivers, but the relation between international trade and water management is generally not something that water sector officials think about. The reason is probably because water itself is not traded internationally, due to its bulky properties. Besides, there is no private ownership of water so that it even cannot be traded as in a market (Savenije, 2002). Water sector specialists forget, however, that water is traded in virtual form, i.e. in the form of agricultural and industrial commodities (Hoekstra and Hung, 2005; Chapagain and Hoekstra, 2008). Although invisible, import of 'virtual water' can be an effective means for water-scarce countries to preserve their domestic water resources (Allan, 2001a).

One of the principles widely accepted in water resources management is the subsidiarity principle, according to which water issues should be settled at the lowest community level possible (GWP, 2000). In cases where upstream water users affect downstream users, it has been recognized that it is necessary to take the perspective of a river basin as a whole, considering water as a river-basin resource. Regarding water as a global resource is very uncommon. The Global Water Partnership (GWP, 2000) writes: 'In order to achieve efficient, equitable and sustainable water management [...], a major institutional change will be needed. Both top-down and bottom-up participation of all stakeholders will have to be promoted - from the level of the nation down to the level of a village or a municipality or from the level of a catchment or watershed up to the level of a river basin. The principle of subsidiarity, which drives down action to the lowest appropriate level, will need to be observed.’ There is no word about a global dimension of water governance. 
Considering water management from a local, national or river basin perspective is, however, often insufficient. Many water problems are closely linked to international trade (Hoekstra and Chapagain, 2008). Subsidized water in Uzbekistan is overused to produce cotton for export; Thailand experiences water problems due to irrigation of rice for export; Kenya depletes its water resources around Lake Naivasha to produce flowers for export to the UK and the Netherlands; Chinese rivers get heavily polluted through waste flows from factories that produce cheap commodities for the European market. Not only water problems, but also water solutions have an international trade component. Jordan and various other countries in the Middle East meet their demand for food and save their scarcely available water resources through food imports from overseas (Chapagain et al., 2006a). Mediterranean countries will expectedly experience increased water scarcity due to climate change, forcing them into the direction of increased import of water-intensive products. Apparently there are more connections between seemingly local or national water issues and international trade than recognized at first sight.

This report reviews current knowledge with respect to four questions:

- what is the effect of international trade on domestic water resources?

- what is the effect of water availability on international trade?

- can international trade increase global water-use efficiency?

- what type of international trade rules would promote a more wise use of water worldwide?

But before addressing these questions, we will first consider the characteristics of freshwater that make it different from other resources. The report will be concluded with a discussion of risks and opportunities associated with the intensification of international trade in waterintensive commodities.

\section{What is special about freshwater?}

\section{Freshwater is a scarce resource}

Freshwater is a scarce resource because its annual availability is limited and demand is growing. It is impossible to 'produce' water; one can only deviate or temporarily store natural flows in order to have access to it at another location or point in time. There are, however, sincere limitations to this, since water transfer and storage are due to different sorts of constraints. First of all, because water is bulky, transferring or storing is quite costly, requiring large infrastructure. Second, taking water out of its natural flow and returning it elsewhere or at another point in time will influence ecosystems that are adapted to the natural flow. Significant changes to natural flows generally have undesired consequences for both downstream ecosystems and downstream users.

\section{Freshwater is a renewable but finite resource}

Water is a renewable resource, but that does not mean that its availability is unlimited. In a certain period, precipitation is always limited to a certain amount. The same holds for the 
amount of water that recharges groundwater reserves and that flows through a river. Rainwater can be used in agricultural production and water in rivers and aquifers can be used for irrigation or industrial or domestic purposes. But in a certain period one cannot use more water than is available. One cannot take more from a river than what flows in it and in the long term one cannot take more water from lakes and groundwater reservoirs than the rate with which they are recharged. Water is a basic resource, one cannot 'make' it, but will have to rely on what is naturally available.

\section{Freshwater can be 'overexploited'}

There are many spots in the world where serious water depletion or pollution takes place: rivers running dry, dropping lake and groundwater levels and endangered species because of contaminated water. 'Available' does not mean that water can always be fully consumed without undesired consequences.

\section{Freshwater is a public resource}

Everywhere in the world, freshwater is a public resource. People can own the land but not the freshwater that stays or flows on or underneath it. Freshwater is neither privately owned nor traded. When the term 'water privatization' is used, one generally refers to the privatization of water supply, which means that the services of collecting, purifying and distributing and/or the services of wastewater collection and treatment are privatised. The term does not mean that the water itself is privatized.

\section{Freshwater availability strongly varies in time}

Many regions in the world face both water scarcity and flooding. Scarcity happens in the dry period, flooding in the wet period of the year. The competition for and economic value of the water fluctuates accordingly throughout the year. This is a very specific property of freshwater, a property that one cannot find for other resources or commodities.

\section{Freshwater availability strongly varies in space.}

The amount of fresh water varies strongly over space as well. In this respect, freshwater is just like oil. Some countries have a lot of it, while others don't. Freshwater is a geopolitical resource in a similar way as oil (Hoekstra and Chapagain, 2008). Abundance of oil or freshwater gives a comparative economic advantage in goods that require a lot of energy or freshwater respectively, but also constitutes a form of political power (Allan, 2001b).

\section{Freshwater productivity strongly varies}

Water productivities - defined as the output per unit of water volume consumed - vary strongly from place to place. This is not just a matter of available technology or available human, social or institutional capital. Water productivity is also related to climate. From a climate and soil perspective, the water of the Nile can be made more productive for making crops in the highlands of Ethiopia than for making the same crops downstream in the desert of Egypt. In this particular case, however, the actual water productivity in Egypt reaches close to its potential, while in Ethiopia, the actual productivity is far below its potential, so that Egypt's actual water productivity is still higher. The fact that different countries have 
different water productivities creates a comparative advantage for those countries that have relatively high water productivity in producing particular water-intensive crops. This is, however, theoretical rather than practical, because real economic costs of water inputs are never fully charged to the water users, so that water will not be a decisive factor in production, unless in cases where water shortages will simply hamper production.

\section{Freshwater is generally priced far below its economic value}

Most governments subsidise water supply on a huge scale by investing in infrastructure like dams, canals, water purification, distribution systems, desalination plants and wastewater treatment. These costs are often not charged to the water users. As a result, there is insufficient economic incentive for water users to save water. Besides, due to the public character of water, water scarcity is generally not translated into an additional component in the price of goods and services that are produced with the water, as happens naturally in the case of private goods. Finally, water users generally do not pay for the negative impacts that they cause on downstream people or ecosystems. As a result, water inputs do not form a substantial component of the total price of even the most water-intensive products. Consequently, the production of and trade in goods - even though various sorts of goods require a lot of scarce water inputs - is not or hardly governed by water scarcity. The only constraint on production is absolute water scarcity: when the river is dry there will be no further use. As Yang et al. (2003) have shown, absolute water scarcity indeed hampers production and necessitates imports of water-intensive goods like cereals in the most waterscarce regions of the world.

\section{Water is not being traded}

When people speak about 'water markets' or 'water trading' they refer to the trade of water use rights, also briefly called water rights or water entitlements. Only a few countries or states - like Chile and California - do have such 'water markets' but most countries don't have that. In water markets, the water is not really traded as in the case of other physical commodities. It are the water use rights that are traded. In the field, this means that one farmer can irrigate his field with a certain amount of water, and not another farmer, when the first one holds the water use right. Or one industry can withdraw some volume of water and not another one that lives along the same river or above the same aquifer. The only form of water trade occurs in the form of trade in bottled water (Gleick, 2004) and beverages. This sort of trade, however, concerns relatively small volumes. People drink no more than a few litres of water per day, while the total water use per capita - for producing all goods and services consumed - amounts to at least a few thousands of litres per day.

\section{International real and virtual water transfers}

International trade in bottled drinking water and beverages does exist but is very small from a volume perspective. From a hydrological point of view it is irrelevant. Bulky international water trade does hardly exist. Freshwater crosses international borders in the case of transboundary rivers like the Nile, Mekong or Danube, but otherwise there are only rare instances of international water transfers. A recent example was in spring 2008 when the Spanish city of Barcelona had to ship in freshwater from France. Various islands, including Aruba, Nauru, 
Tonga and the Canary Islands have at times received freshwater by tanker from elsewhere (Gleick et al., 2002). Much larger-scale international water transfers have been proposed throughout the world, like the idea of transferring water from Congo to Chad or from Northern Russia and Siberia to Central Asia. Whether these mega-engineering plans will be realised is doubtful, due to the enormous costs and social and environmental consequences. At least until date one can say that international water trade or transfers are very small on a global scale. What happens, however, on a very substantial scale, is transfer of water in embedded form, i.e. in the form of goods. It is not that the amounts of water actually contained in goods are so large, but the water volumes virtually embedded in goods can be huge. By consuming water in one country to produce a product that is traded to another country, the water is virtually transferred to the importing country. In this context we speak about 'virtual water trade', although 'transfer' would be a better term, because the goods are traded, not the water.

\section{The effect of international trade on domestic water resources}

An obvious effect of international trade in water-intensive commodities is that it generates water savings in the countries that import those commodities. This effect has been discussed since the mid-1990s (Allan, 2001b; Hoekstra, 2003). The national water saving associated with import can be estimated by multiplying the imported product volume by the volume of water that would have been required to produce the product domestically. The other side of international trade in water-intensive commodities is that takes water in the exporting countries that can no longer be used for other (domestic) purposes. Besides, the social and environmental costs that are often associated with water use remain in the exporting countries; they are not included in the price paid for the products by the consumers in the importing countries.

\subsection{Import of water-intensive commodities reduces national water demand}

In many countries international trade in agricultural products effectively reduces domestic water demand (Table 1). These countries import commodities that are relatively waterintensive while they export commodities that are less water-intensive. In the period 19972001, Japan, the largest (net) importer of water-intensive goods in the world, annually saved 94 billion $\mathrm{m}^{3}$ from its domestic water resources. This volume of water would have been required, in addition to its current water use, if Japan had produced all imported products domestically. In a similar way, Mexico annually saved 65 billion $\mathrm{m}^{3}$, Italy 59 billion $\mathrm{m}^{3}$, China 56 billion $\mathrm{m}^{3}$, and Algeria 45 billion $\mathrm{m}^{3}$ (Chapagain et al., 2006a). 
Table 1. Examples of nations with net water saving as a result of international trade in agricultural products. Period 1997-2001.

\begin{tabular}{|c|c|c|c|c|c|}
\hline Country & $\begin{array}{c}\text { Total use of } \\
\text { domestic water } \\
\text { resources in } \\
\text { the agricultural } \\
\text { sector }{ }^{1} \\
\left(10^{9} \mathrm{~m}^{3} / \mathrm{yr}\right)\end{array}$ & $\begin{array}{l}\text { Water saving as } \\
\text { a result of } \\
\text { import of } \\
\text { agricultural } \\
\text { products } \\
\left(10^{9} \mathrm{~m}^{3} / \mathrm{yr}\right)\end{array}$ & $\begin{array}{c}\text { Water loss as a } \\
\text { result of export } \\
\text { of agricultural } \\
\text { products } \\
\left(10^{9} \mathrm{~m}^{3} / \mathrm{yr}\right)\end{array}$ & $\begin{array}{l}\text { Net water } \\
\text { saving due to } \\
\text { trade in } \\
\text { agricultural } \\
\text { products }^{2} \\
\left(10^{9} \mathrm{~m}^{3} / \mathrm{yr}\right)\end{array}$ & $\begin{array}{l}\text { Ratio of net } \\
\text { water } \\
\text { saving to } \\
\text { use of } \\
\text { domestic } \\
\text { water }\end{array}$ \\
\hline China & 733 & 79 & 23 & 56 & $8 \%$ \\
\hline Mexico & 94 & 83 & 18 & 65 & $69 \%$ \\
\hline Morocco & 37 & 29 & 1.6 & 27 & $73 \%$ \\
\hline Italy & 60 & 87 & 28 & 59 & $98 \%$ \\
\hline Algeria & 23 & 46 & 0.5 & 45 & $196 \%$ \\
\hline Japan & 21 & 96 & 1.9 & 94 & $448 \%$ \\
\hline
\end{tabular}

${ }^{1}$ Source: Hoekstra and Chapagain (2008)

${ }^{2}$ Source: Chapagain et al. (2006a). Agricultural products include both crop and livestock products.

One of the water-scarce countries that most heavily depend on imports of water-intensive commodities is Jordan. It imports five to seven billion $\mathrm{m}^{3}$ of water in virtual form per year, which is in sharp contrast with the 1 billion $\mathrm{m}^{3}$ of water withdrawn annually from domestic water sources (Haddadin, 2003; Hoekstra and Chapagain, 2007, 2008). People in Jordan thus survive owing to the fact that their 'water footprint' has largely been externalized to other parts of the world, for example the USA. Intelligent trade largely covers up Jordan's water shortage: export of goods and services that require little water and import of products that need a lot of water. The good side of Jordan's trade balance is that it preserves the scarce domestic water resources; the downside is that the people are heavily water dependent.

For countries that depend on the import of water-intensive products, it is important to know whether the water thus saved has higher marginal benefits than the additional cost involved in importing these products. Let us consider the example of Egypt, a country with a very low rainfall - the mean rainfall is only $18 \mathrm{~mm} / \mathrm{yr}$ - and with most of its agriculture being irrigated. The import of wheat in Egypt implies a saving of their domestic water resources of 3.6 billion $\mathrm{m}^{3} / \mathrm{yr}$, which is about $7 \%$ of the total volume of water Egypt is entitled to according to the 1959 agreement on the use of the Nile River. The national saving is made with the investment of foreign exchange of 593 million US\$/yr (ITC, 2004), so that the cost of the virtual water is $0.16 \mathrm{US} \$ / \mathrm{m}^{3}$ at most. In fact, the cost will be much lower, because the costs of the imported wheat cover not only the cost of water, but also the costs of other input factors such as land, fertilizer, and labour. In Egypt, fertile land is also a major scarce resource. The import of wheat not only releases the pressure on the disputed Nile water, but also reduces pressure to increase the area of land under agriculture. Greenaway et al. (1994) and Wichelns (2001) have shown that in the international context Egypt has a comparative disadvantage in the production of wheat, so that the import of wheat into Egypt implies not only a physical water saving, but also an economic saving. 


\subsection{Export of water-intensive commodities raises national water demand}

Water is not merely a local resource to meet local demands for water-based products. In the period 1997-2001, sixteen per cent of the water use in the world was not for producing products for domestic consumption but for making products for export (Hoekstra and Chapagain, 2007, 2008). The nations with the largest net annual water use for producing export products were the USA (92 billion $\mathrm{m}^{3}$ ), Australia (57 billion $\mathrm{m}^{3}$ ), Argentina (47 billion $\mathrm{m}^{3}$ ), Canada (43 billion $\mathrm{m}^{3}$ ), Brazil (36 billion $\mathrm{m}^{3}$ ), and Thailand (26 billion $\mathrm{m}^{3}$ ). The main products behind the national water use for export from the USA were oil-bearing crops and cereal crops. These products are grown partly rain-fed and partly irrigated. In Australia and Canada, the water use for export was mainly related to the production of cereals and livestock products. In Argentina and Brazil, water use for export was primarily for producing oilbearing crops. The national water use for export in Thailand was mainly the result of export of rice. Much of the rice cultivation in Thailand is done during the rainy season, but irrigation is widespread, to achieve two harvests per year. In the period 1997-2001, Thailand used 27.8 billion $\mathrm{m}^{3} / \mathrm{yr}$ of water (sum of rainwater and irrigation water) to produce rice for export, mostly grown in the central and northern regions (Maclean et al., 2002). The monetary equivalent of the rice export was 1,556 million US\$/yr (ITC, 2004). Hence, Thailand generated a foreign exchange of $0.06 \mathrm{US} \$ / \mathrm{m}^{3}$.

Let me repeat that currently sixteen per cent of the water use in the world is not for producing products for domestic consumption but for making products for export and let us simply assume that, on average, agricultural production for export does not cause significantly more or fewer water-related problems (such as water depletion or pollution) than production for domestic consumption. That means that roughly one sixth of the water problems in the world can be traced back to production for export. Consumers do not see the effects of their consumption behaviour due to the tele-connection between areas of consumption and areas of production. The benefits are at the consumption side, but since water is generally grossly under-priced, the costs remain at the production side. From a water-resources point of view it would be wise for the exporting countries in the world to review their water use for export and see to which extent this is good policy given the fact that the foreign income associated with the exports generally does not cover most of the costs associated with the use of water. The construction of dams and irrigation schemes and even operation and maintenance costs are often covered by the national or state government. Negative effects downstream and the social and environmental costs involved are not included in the price of the export products as well.

\subsection{The effect of international trade on local water pollution}

International trade brings along another phenomenon: natural cycles of nutrients such as nitrogen and phosphorus are disturbed through depletion of the soil in some places, excessive use of fertilizers in others, long-distance transfers of food and animal feed and concentrated disposal of nutrient-rich wastes in densely populated areas of the world (Grote et al., 2005). 
This has already led and will further lead to depletion of the soil in some areas (Sanchez, 2002; Stocking, 2003) and eutrophication of water elsewhere (McIsaac et al., 2001; Tilman et al., 2001). The surplus of nutrients in the Netherlands, for instance, is partially related to deforestation, erosion and soil degradation in those areas of the world that export food and feed to the Netherlands, for example in Brazil from where a lot of soybeans for the Dutch pigs and chickens are imported. This implies that the nutrient surplus in the Netherlands is not an issue that can simply be understood as a Dutch issue. Dutch water pollution is part of the global economy.

The disturbance of nutrient cycles is not the only mechanism through which international trade influences the quality of water resources worldwide. Meybeck (2004) shows how other substances are also dispersed into the global environment and change the quality of the world's rivers. Nriagu and Pacyna (1988) set out the specific impacts of the use of trace metals in the global economy on the world's water resources. The regular publication of new reports on global pollution shows that this phenomenon in itself is no longer news; what is now gradually being uncovered and therefore relatively new is the fact that pollution is not simply 'global' because pollution is so 'widespread', but that it is interlinked with how the global economy works and is therefore a true global problem. Water pollution is intertwined with the global economic system to such an extent that it cannot be dealt with independently from that global economy. Indeed, pollution can be tackled by end-of-pipe measures at or near the location of the pollution, but a more cause-oriented approach would be restructuring the (rules for the) global economy, with the aim of the closure of element cycles.

\section{The effect of water availability on international trade}

There is an immense volume of literature about international trade, but there are few scholars who address the question to which extent international trade is influenced by regional differences in water availability. International trade is rather explained in terms of differences in labour productivities, availability of land, domestic subsidies to agriculture, import taxes, production surpluses and associated export subsidies, etc. It will be hard to find evidence that regional water abundance benefits the export of water-intensive commodities and that regional water scarcity promotes the import of water-intensive commodities.

According to international trade theory that goes back to Ricardo ([1817] 2006), nations can gain from trade if they specialize in the production of goods and services for which they have a comparative advantage, while importing goods and services for which they have a comparative disadvantage. The meaning of the principle for the field of water resources has been elaborated by Wichelns (2004). The economic efficiency of trade in a water-intensive commodity between two countries should be evaluated based on a comparison of the opportunity costs of producing the commodity in each of the trading nations. Export of a water-intensive commodity is attractive if the opportunity cost of producing the commodity is comparatively low. This is the case when there is a relatively high production potential for the water-intensive commodity due to for example relative abundance of water and/or a relatively high water productivity (yield per unit of water input) in the country. Import of a 
water-intensive commodity (instead of producing it domestically) is attractive if the opportunity cost of producing the commodity is comparatively high, for example because water is relatively scarce and/or water productivity in the country is low.

The most convincing research providing evidence that water availability influences international trade has been carried out by Yang et al. (2003, 2007). As they have quantitatively shown, cereal imports have played a crucial role in compensating water deficits in various water-scarce countries. They demonstrate that below a certain threshold in water availability, an inverse relationship can be identified between a country's cereal import and its per capita renewable water resources. In the early 1980s the threshold was at about 2000 $\mathrm{m}^{3}$ per capita per year. At the end of the 1990s it had declined to about $1500 \mathrm{~m}^{3}$ per capita per year. Countries with less water than the threshold cannot do without the import of staple foods. The threshold declined over the past couple of decades due to the improvement in water productivities and the expansion of irrigated areas.

There is clear evidence that the trade balance of countries with very low water availability (per capita) is partly determined by the fact that those countries have a comparative disadvantage in producing water-intensive products. One does not need to be economist to see that; the available water resources simply fall short in some countries to produce the food to survive. Most international trade in the world, however, has little to do with the intentional trade in water-intensive commodities to countries with low water availability from countries with higher water availability. The driving force behind international trade in water-intensive products can be water scarcity in the importing countries, but more often other factors play a decisive role (Yang et al., 2003; De Fraiture et al., 2004).

International trade in agricultural commodities depends on many more factors than differences in water scarcity in the trading nations, including differences in availability of land, labour, knowledge, and capital, and differences in economic productivities in various sectors. The existence of domestic subsidies, export subsidies, or import taxes in the trading nations will also influence the trade pattern. As a consequence, international virtual-water transfers usually cannot - or can only partly - be explained on the basis of differences in water availability and productivity.

In some cases, the relation between water availability and the actual trade pattern is even counter-intuitive. North China for instance has a very low availability of water per capita, unlike South China, but nevertheless, there is a very significant trade in food from North to South China (Ma et al., 2006). Of course, this does intensify the water problems in the North. A similar case can be found in India, where water has become relatively scarce in the northern states of Punjab, Uttar Pradesh and Haryana. Nevertheless, these states export significant volumes of food to the eastern states of Bihar, Jharkhand and Orissa, which have much larger water endowments than the northern states (Verma et al., 2009). No simple explanation will suffice to explain the counter-intuitive situations with respect to the internal trade within China and India, because various factors will play a role, including historical, political and economic ones. One factor that may play a role as well is that in water-scarce 
regions the incentives to increase water productivity are highest. As a result, it becomes attractive to produce in those regions, which however enhances the scarcity of the water. This may be a factor in northern India, where water productivities are indeed much higher than in the eastern states, providing them with a comparative advantage though the water availability in absolute terms is much lower.

Forecasts of how international trade patterns will develop generally ignore water as a possible constraint to production and pay no attention to the role of freshwater in terms of comparative advantage. As a result, some of the scenarios developed predict increased agricultural production in areas where water is already highly scarce or even over-drafted. Liao et al. (2008) illustrate this for the case of China by studying the effect of trade liberalisation that will likely follow China's accession to the World Trade Organization in 2001. They show that existing projections of agricultural production and trade, which ignore water as a production factor, are unrealistic. Including water as a constraint leads to projections where cereal imports into China will be much higher than previously thought and less optimistic prospects with respect to increased export of vegetables.

\section{Global water-use efficiency}

In the water sector, the term water-use efficiency is most often used to refer to the inverse of local water productivity. The latter is expressed as the amount of product made per unit of water (in the agricultural sector known as 'crop per drop'). The water-use efficiency is expressed as the volume of water required to make one unit of product. A water user can increase local water-use efficiency by producing the same with less water input. Water users can be encouraged to do so by charging them a water price that is based on full marginal cost, by stimulating them to adopt water-saving technology, or by creating awareness that saving water is good for the environment.

The local view on water-use efficiency is only one way of looking at water-use efficiency. There are two other levels at which one can consider the efficiency of water use (Hoekstra and Hung, 2005). At the catchment or river basin level, water-use efficiency refers to the efficiency of water allocation to alternative uses. Water-use efficiency at this level can be enhanced by re-allocating water to purposes with higher marginal benefits (Rogers et al., 1998). At the global level, water-use efficiency can be increased if nations use their comparative advantage or disadvantage in producing water-intensive goods to either encourage or discourage the use of domestic water resources for producing export commodities.

Much research effort has been dedicated to studying water-use efficiency at the local and river basin levels. The research on global water-use efficiency is of more recent date. Only four studies have been carried out so far, all of them focusing on the quantification of physical water savings as a result of global trade, not on the economic savings associated. All four studies indicate that the current pattern of international trade results in a substantial 
global water saving (Oki and Kanae, 2004; De Fraiture et al., 2004; Chapagain et al., 2006a; Yang et al., 2006).

\subsection{Volume of water saved as a result of international trade}

The most comprehensive study on global water saving in relation to international trade was the one carried out by Chapagain et al. (2006a). According to their study, the global water use for producing agricultural products for export amounted to 1,250 billion $\mathrm{m}^{3} / \mathrm{yr}$ (in the period 1997-2001). If the importing countries were to have produced the imported products domestically they would have required a total of 1,600 billion $\mathrm{m}^{3} / \mathrm{yr}$. This means that the global water saving by trade in agricultural products was 350 billion $\mathrm{m}^{3} / \mathrm{yr}$. So the average water saving accompanying international trade in agricultural products has been $(350 / 1,600=)$ $22 \%$. The global volume of water used for agricultural production is 6,400 billion $\mathrm{m}^{3} / \mathrm{yr}$. Without trade, supposing that all countries had to produce the products domestically, agricultural water use in the world would amount to 6,750 instead of 6,400 billion $\mathrm{m}^{3} / \mathrm{yr}$. International trade thus reduces global water use in agriculture by $5 \%$.

Above figures do not differentiate between the use of green water (rainwater) and the use of blue water (ground and surface water). The global water saving associated with a certain trade flow can refer to either a global blue or a global green water saving (or a combination of both). Even if there is a net global water loss from a trade relation, there might be a saving of blue water at the cost of a greater loss of green water or vice versa. From an economic point of view there is a substantial difference between blue and green water saving, because the opportunity costs of blue water are generally much higher than the opportunity costs of green water. As a result, trade with an associated blue water saving but a greater green water loss could still be efficient from an economic point of view.

\subsection{The downside of virtual-water trade as a solution to water scarcity}

Saving domestic water resources in countries with relative water scarcity through virtualwater import (import of water-intensive products) looks very attractive. There are however a number of drawbacks that have to be taken into account. First, saving domestic water through import should explicitly be seen in the context of the need to generate sufficient foreign exchange to import food which otherwise would be produced domestically. Some waterscarce countries in the world are oil-rich, so they can easily afford to import water-intensive commodities. However, many water-scarce countries lack the ability to export energy, services or water-extensive industrial commodities in order to afford the import of waterintensive agricultural commodities. Second, import of food carries the risk of moving away from food self-sufficiency. This plays an important role in the political considerations in countries such as China, India and Egypt. Third, import of food will be bad for the domestic agricultural sector and lead to increased urbanization, because import reduces employment in the agricultural sector. It will also result in an economic decline and worsening of land management in rural areas. Fourth, in many water-scarce developing countries, where an important part of the agriculture consists of subsistence farming, promoting food imports may 
threaten the livelihoods of those subsistence farmers and reduce access to food for the poor. Finally, increases in virtual-water transfers to optimize the use of global water resources can relieve the pressure on water-scarce countries but may create additional pressure on the countries that produce the water-intensive commodities for export. The potential water saving from global trade is sustainable only if the prices of the export commodities truly reflect the opportunity costs and negative environmental impacts in the exporting countries. Otherwise the importing countries are simply gaining from the fact that they would have had to bear the cost of water depletion if they had produced domestically whereas the costs remain external if they import the water-intensive commodities instead.

\section{What sort of international trade rules would contribute to a better use of the world's scarce water resources?}

\subsection{The principles of product transparency and non-discrimination}

The basis for well-informed consumer action, governmental policy and company strategy is product transparency. As I would define it, the product-transparency principle requires that all relevant information about a product is publicly available, including both information about the product as it appears and information about how it is produced. When we limit ourselves here to how a product relates to the use of freshwater, relevant information may include for instance answers to questions such as: how much water was consumed to make the product in the different stages of its supply chain, how much water was polluted, what type of pollution, does the water consumption or pollution takes place in areas where water is relatively scarce and already polluted beyond acceptable limits, are downstream users or ecosystems negatively affected, could the water consumed have been used for an alternative purpose with a higher societal benefit, etc. Products may often look alike - same colour, smell, feel, taste, quality - but nevertheless they may be quite different. Every product has a unique history. The origin of the ingredients may differ as well as the production circumstances of the ingredients. A beverage like cola contains sugars which can come for instance from sugar beet, sugar cane or maize (high-fructose maize syrup). The crop may be grown with irrigation water from the overexploited Ogallala Aquifer beneath the Great Plains in the United States or under rain-fed conditions in a water-abundant part of Europe. In other words, one bottle of cola is simply not equal to another. Similar appearance, but different history. Production circumstances can vary among countries, but also within countries; differences can exist between brands, but also within brands and even between different batches of otherwise precisely the same product. From a water-footprint perspective, one may like to discriminate between seemingly similar goods, based on the different impacts the goods have on freshwater resources. Chapagain et al. (2006b) show for example how the water footprint of cotton consumed in Europe strongly depends on the region of origin (Figure 1). Cotton from Uzbekistan and Pakistan, for example, has a relatively large water footprint on blue water resources and can be associated with the desiccation of the Aral Sea and intensive use and pollution of the Indus river, respectively. 


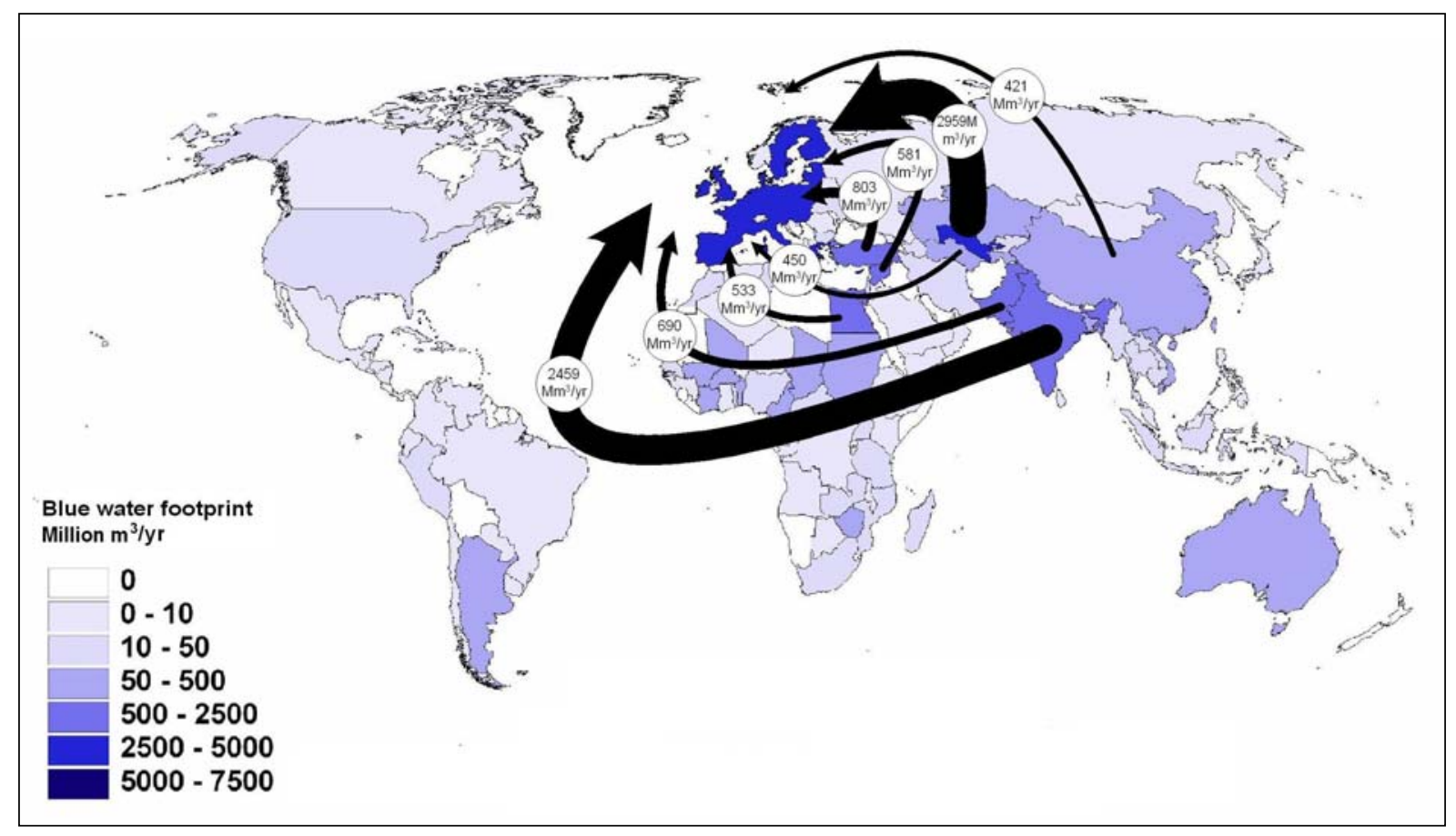

Figure 1. The global water footprint of cotton consumption in the European Union. Source: Chapagain et al. (2006).

An important principle used in the context of international trade negotiations is the 'nondiscrimination principle'. The principle says that the international trading system should be without discrimination, which means that a country should not discriminate between its trading partners nor between its own and foreign products (WTO, 2008). A key question to be posed in this context is what are the criteria to evaluate whether two goods can be called similar. According to the non-discrimination principle, one may not discriminate between cotton from one and cotton from another country or between beef from one and beef from another country. But what does the principle say if it appears that two similar products are not similar at all? Discrimination is considered unfair when products are similar, but discrimination is quite natural when products are not similar.

Fair international trade rules should include a provision that enables consumers, through their government, to raise trade barriers against products that are considered unsustainable, or more in particular, in the context of this paper, are kept responsible for harmful effects on water systems and indirectly on the ecosystems or communities that depend on those water systems. In practice, this means that the non-discrimination principle would hold only for similar products that are considered also similar in terms of the existing impacts along their supply chain. It would imply that a country can favour import of a certain product from a country that can guarantee that the product's water footprint is not located in catchments where environmental flow requirements are violated or where ambient water quality standards are not met. This favour would have to hold - according to the non-discrimination principle - for all countries that can give that guarantee. Such guarantee can be provided only 
when proper arrangements for product transparency are in place. The favour, however, would not necessarily hold for countries that cannot provide that guarantee.

When arrangements for product transparency in a particular country are in place, it can occur that one set of goods of a certain kind from that country does fulfil a set of specified sustainability requirements, while another set of goods of the same kind does not. In that case another country may be willing to have free trade with respect to the first set of goods, but to raise trade barriers with respect to the other set of goods. It seems justified to allow for such arrangements in international trade rules. Countries can either choose to agree on shared criteria for sustainability requirements, which can then be included in an international trade agreement, or they can leave the formulation of such criteria to each country separately. The former situation may be preferable, because it creates equity and security on the market, but it will be at the cost of national sovereignty to quickly respond to new developments and adapt criteria. Besides, countries may have highly divergent opinions about what criteria should be chosen. Anyhow, trying to agree on shared criteria on product sustainability can be part of international negotiations. This should be in a different context than the World Trade Organization, because the WTO limits itself to trade negotiations and refrains from negotiations on environmental protection. For environmental protection, the WTO refers to multilateral environmental agreements formulated in other international settings. According to WTO rules, a trade dispute that falls under a certain multilateral environmental agreement signed by two conflicting countries, should be settled using the environmental agreement.

\subsection{The imbalance between international trade agreements and international agreements on sustainable water use}

In the perspective of the WTO, 'free trade' is not at odds with 'green trade'. National governments have negotiated WTO rules voluntarily. Similarly, national governments negotiate and agree on international environmental agreements. If a dispute arises over a trade action taken under an environmental agreement, and if both sides to the dispute have signed that agreement, then they should try to use the environmental agreement to settle the dispute. However, if one side in the dispute has not signed the environmental agreement, then the WTO would provide the only possible forum for settling the dispute (WTO, 2008, p.67). Besides, it matters whether an international agreement contains rules that relate to trade or not. As Neumayer (2004) observes, most regional or international environmental agreements do not contain any trade-restrictive measures. As a result, these environmental agreements will be irrelevant, i.e. ignored, when settling a trade dispute. In the case in which an international environmental agreement is absent at all and where a trade barrier is raised with reference to national environmental legislation, it will again be the WTO to settle the dispute. Historic evidence is that free trade rules agreed internationally within the context of the WTO go beyond environmental protection rules set by national governments or international environmental agreements not signed by one of the parties of the dispute. According to the WTO, if trade barriers could be raised with reference to national regulations, "then any country could ban imports of a product from another country merely because the exporting country has different environmental, health and social policies from its own. This would 
create a virtually open-ended route for any country to apply trade restrictions unilaterally and to do so not just to enforce its own laws domestically, but to impose its own standards on other countries” (WTO, 2008, p.70).

Internationally binding agreements on sustainable water use or, more particularly, on 'sustainable water use in the production of goods and services' do not exist. The reason is probably that - as set out in the introduction - freshwater is primarily seen as a local resource, to be managed at the level of a nation or river basin at most. As a result, policies for water governance are always shaped in the form of national legislation, supplemented by international agreements on trans-boundary rivers and agreements on a regional level like in the European Union. This means that whenever trade disputes with reference to freshwater protection arise, the dispute will be settled under WTO and that - with reference to the nondiscrimination principle - the outcome will be in favour of free trade and not freshwater protection.

In the international arena, there is no legal basis to discriminate in international trade based on environmental product standards. This is a fundamental imbalance in the area of international agreements. In the WTO, international trade rules do not necessarily go beyond international environmental agreements, but in case of absence of the latter, the international trade rule of non-discrimination becomes decisive. The WTO agreements are interpreted to say two important things: "First, trade restrictions cannot be imposed on a product purely because of the way it has been produced. Second, one country cannot reach out beyond its own territory to impose its standards on another country" (WTO, p.66). Given the fact that many products on the world marker have significant impacts on freshwater systems, by contributing to the violation of local environmental flow requirements or ambient water quality standards, it is expected that consumers will increasingly demand for product transparency and it is likely that consumers in some countries will start to ask their government to ban imports of products that obviously do not meet domestic standards. Given the current conditions it is very unlikely that national efforts to ban products with reference to national standards on sustainable water use will succeed. This raises the question which instruments are left to national governments to ensure that internationally traded products are based on a sustainable use of freshwater. In the next two sections, three different sorts of possible international arrangements are being discussed: an international water pricing protocol, a water label for products, and an international water-footprint permit system.

\subsection{International Water Pricing Protocol}

A major issue when talking about good water governance and international trade is the fact that particularly the international market in agricultural products is heavily distorted. Since $85 \%$ of global water consumption occurs in agricultural production (Hoekstra and Chapagain, 2008), this is highly relevant for water. The distortion is related to all sorts of direct and indirect subsidies that agriculture receives in all countries in the world, albeit in different forms per country. This issue is widely known, but most discussion is about direct subsidies to farmers and about export subsidies and import taxes. Much less attention is to the fact that 
water as a major input factor to agriculture is generally hugely underpriced. The result is that water is no factor of importance in the establishment of production and trade patterns. This results in perverse trade flows, where water-intensive crops are exported on a large scale from areas where water is highly scarce and overexploited. Free trade will never contribute to optimal production and trade outcomes from a water-perspective as long as water remains so much underpriced.

There is a need to arrive at a global agreement on water pricing structures that cover the full cost of water use, including investment costs, operational and maintenance costs, a water scarcity rent and the cost of negative externalities of water use (Hoekstra, 2006; Hoekstra and Chapagain, 2008; Verkerk et al., 2008). Without an international treaty on proper water pricing it is unlikely that a globally efficient pattern of water use will ever be achieved. The need to have full cost pricing has been acknowledged since the Dublin Conference in 1992 (ICWE, 1992). A global ministerial forum to come to agreements on this does exist in the regular World Water Forums (Marrakech 1997, The Hague 2000, Kyoto 2003, Mexico City 2006, Istanbul, 2009), but these forums have not been used to take up the challenge of making international agreements on the implementation of the principle that water should be considered as a scarce, economic good. The World Water Forums are not organised under the umbrella of a UN organisation. Alternative forums to initiate and negotiate an international Water Pricing Protocol could be UN-Water or the UN Commission on Sustainable Development (CSD).

It is not sufficient to leave the implementation of the water-is-an-economic-good principle to national governments without having some kind of international protocol on the implementation, because unilateral implementation can be expected to be at the cost of the countries moving ahead. The competitiveness of the producers of water-intensive products in a country that one-sidedly implements a stringent water pricing policy will be affected, and this, together with the natural resistance of domestic consumers to higher prices of local products, will reduce the feasibility of a unilateral implementation of a rigorous water pricing strategy. An international protocol on full-cost water pricing would contribute to the sustainable use of the world's water resources, because water scarcity would be translated into a scarcity rent and thus affect consumer decisions, even if those consumers live at a great distance from the production site. Such a protocol would also contribute to fairness, by making producers and consumers pay for their contribution to the depletion and pollution of water. Finally, such a protocol would shed a fresh light upon the economic feasibility of plans for large-scale inter-basin transfers, since it would force negative externalities and opportunity costs to be taken into account. Full-cost water pricing should be combined with a minimum water right, in order to prevent poor people not being able to obtain their basic needs (Gleick, 1999; Mehta and La Cour Madsen, 2005).

\subsection{An international water label for water-intensive products}

The necessity of product transparency could be translated into a water label. This term should be understood in very broad terms here, because it could be a label physically attached to a 
product, but also digital information about a specific product available through internet by scanning its barcode in the shop or at home. Furthermore, it could be a simple label showing whether a product meets a certain set of sustainability criteria (a yes or no label), but it could also be a more advanced label with detailed quantitative information on a number of relevant criteria. Introducing such a label would be most relevant for water-intensive products, i.e. products that are usually related to relative big volumes of water consumption and/or pollution. The label could be introduced first for a few commodities that usually have great impacts on water systems, such as rice, cotton, paper and cane sugar. Given the global character of the rice, cotton, paper and sugar markets, international cooperation in setting the labelling criteria and in the practical application of the water label is a precondition. Consideration could be given to integrating the water label within a broader environmental label, but this would probably create new bottlenecks for implementation, so that a first step could be to agree on a separate water label.

Supposed that one or a number of countries would agree on some sort of water-labelling scheme, it is unclear how current WTO rules have to be interpreted when a dispute would arise. Consider the case in which a country raises a trade barrier for all countries that do not fulfil the requirements of the water-labelling scheme. Given the decisions made in earlier disputes (consider for instance the so-called tuna-dolphin dispute between the USA and Mexico), the WTO rules are unlikely to lead to acceptance of discrimination of products from a country not fulfilling a certain labelling requirement if that country has not signed up for that labelling scheme. The WTO finds that one country cannot impose its own environmental regulations on another country. It is to be noted, however, that some commentators have argued that under some conditions it is possible for WTO members to impose environmental regulations on another member (Charnovitz, 2002). Altogether, there is still much ambiguity about the role national environmental standards related to processes and production methods can have in restricting international trade. This underlines the necessity to come to broad international agreements on a water-labelling scheme. Without international agreement, any labelling scheme will be useful for domestic products only and unlikely be effective in restricting trade. In the case that countries would agree on an international water label, this label will likely be covered by WTO’s Technical Barriers to Trade (TBT) Agreement, which has been designed to ensure that regulations, standards, testing and certification procedures do not create unnecessary obstacles to trade. This means that the labelling scheme should fulfil a set of conditions set by the WTO.

Given the fact that a broad international water label laid down in an international agreement is far from reality, liberalisation of trade in water-intensive products under WTO makes it more difficult if not impossible for countries to take action against products from countries that are considered as undesirable because they either lack transparency or are transparent but do not meet certain domestically defined sustainability standards. Under existing WTO rules, countries have to let products that do not meet production-standards enter the country at the same conditions as similar products that do meet the standards. The only remaining choice is that consumers select themselves in the shop. This choice will be hampered, however, by lack of information, because countries cannot impose a labelling scheme on imported products. 


\subsection{An International Water-Footprint Permit System}

The limited availability of freshwater in the world implies a ceiling for humanity's water footprint. The question for the global community is how this global maximum can be transferred to the national or even the individual level. Or in other words: what is each nation's and each individual's 'reasonable' share of the globe's water resources? And what mechanisms could be established in order to achieve that people do not use more than their 'reasonable' share? Maximum levels of water use to guarantee a sustainable use could be institutionalized in the form of a water footprint permit system (Hoekstra, 2006; Hoekstra and Chapagain, 2008; Verkerk et al., 2008). An international protocol on establishing water footprint permits would be comparable to the Kyoto Protocol on the emission of greenhouse gases (drafted in 1997, effective since 2005). The Kyoto Protocol is based on the understanding that, to prevent human-induced climate change, there is a ceiling on the maximum volume of greenhouse gas emissions from human activities that can be accommodated by the global system.

In an international water-footprint permit system, permits would be issued per nation. Alternatively, the permits can take the form of water-footprint reduction targets compared to a certain reference year or period. Nations would be responsible for translating the targets into national policy in order to meet the target or remain within the permit. Enforcement could be done in the form of penalties when not meeting the agreed targets. Targets would need to be specified for example by water footprint component (green, blue, grey water footprint); they could also be specified by sector or product category.

\subsection{The Doha Development Round}

The WTO rules apply to most products but still exclude or include to a limited extent services and agricultural products. Because $85 \%$ of the water consumption in the world occurs in agriculture, concerns with respect to sustainable freshwater use can still be taken into account in the negotiations in the Doha Development Round, the current trade-negotiation round of the World Trade Organization which started in 2001. Trade in agricultural products is one of the key focus areas of the current negotiations. As follows from above, from a sustainablewater-use perspective it is key that any new rules on international trade in agricultural products include provisions that ensure that efforts to contribute to more sustainable water use behind the products traded are promoted and rewarded.

\section{Discussion}

International transfers of water in virtual form are substantial and likely to increase with continued global trade liberalization (Ramirez-Vallejo and Rogers, 2004). Intensified trade in water-intensive countries offers both opportunities and risks. The most obvious opportunity of reduced trade barriers is that virtual water can be regarded as a possibly cheap alternative source of water in areas where freshwater is relatively scarce. Virtual-water import can be 
used by national governments as a tool to release the pressure on their domestic water resources. This import of virtual water (as opposed to real water, which is generally too expensive) will relieve the pressure on the nation's own water resources. For water-abundant countries an argument can be made for export of virtual water. Trade can physically save water if products are traded from countries with high to countries with low water productivity. For example, Mexico imports wheat, maize, and sorghum from the USA, which requires 7.1 billion $\mathrm{m}^{3}$ of water per year in the USA. If Mexico were to produce the imported crops domestically, it would require 15.6 billion $\mathrm{m}^{3}$ of water per year. Thus, from a global perspective, the trade in cereals from the USA to Mexico saves 8.5 billion $\mathrm{m}^{3} / \mathrm{yr}$. Although there are also examples where water-intensive commodities flow in the opposite direction, from countries with low to countries with high water productivity, the available studies indicate that the resultant of all international trade flows works in a positive direction. We showed that international trade in agricultural commodities reduces global water use in agriculture by $5 \%$. Liberalization of trade seems to offer new opportunities to contribute to a further increase of efficiency in the use of the world's water resources.

A serious drawback of trade is that the indirect effects of consumption are externalized to other countries. While water in agriculture is still priced far below its real cost in most countries, an increasing volume of water is used for processing export products. The costs associated with water use in the exporting country are not included in the price of the products consumed in the importing country. Consumers are generally not aware of - and do not pay for - the water problems in the overseas countries where their goods are being produced. According to economic theory, a precondition for trade to be efficient and fair is that consumers bear the full cost of production and impacts. Another downside of intensive international virtual-water transfers is that many countries increasingly depend on the import of water-intensive commodities from other countries. Jordan annually imports a virtual-water volume that is five times its own annual renewable water resources. Other countries in the Middle East, but also various European countries, have a similar high water import dependency. The increasing lack of self-sufficiency has made various individual countries, but also larger regions, very vulnerable. If for whatever reason food supplies cease - be it due to war or a natural disaster in an important export region - the importing regions will suffer severely. A key question is to what extent nations are willing to take this risk. The risk can be avoided only by promoting national self-sufficiency in water and food supply (as Egypt and China do). The risk can be reduced by importing food from a wide range of trade partners. The current worldwide trend, however, facilitated by the World Trade Organization, is toward reducing trade barriers and encouraging free international trade, and decreasing interference by national governments.

The current global trade pattern significantly influences water use in most countries of the world, either by reducing domestic water use or by enhancing it. Future national and regional water policy studies should therefore include an assessment of the effects of trade on water policy. For water-scarce countries, it would also be wise to do the reverse: study the possible implications of national water scarcity on trade. In short, strategic analysis for water policy 
making should include an analysis of expected or desirable trends in international or interregional virtual-water flows.

International agreements on the liberalization of trade in agricultural products - as being negotiated in WTO's ongoing Doha Development Round - should include provisions that promote sustainable water use in agriculture. As yet it is unclear how such provisions could look like, since the WTO explicitly refrains from making environmental agreements. An imbalance in global regulations of trade will be created as soon as free trade agreements are effective while sustainable-product and sustainable-water-use agreements to constrain international trade are not yet existent. This is a serious risk, since no international agreements on sustainable water use or sustainable products do exist or are being prepared. 


\section{References}

Allan, J.A. (2001a) Virtual water - Economically invisible and politically silent - A way to solve strategic water problems, International Water and Irrigation, Nov: 39-41.

Allan, J.A. (2001b) The Middle East water question: Hydropolitics and the global economy, I.B. Tauris, London, UK.

Chapagain, A.K., Hoekstra, A.Y. and Savenije, H.H.G. (2006a) Water saving through international trade of agricultural products, Hydrology and Earth System Sciences 10(3): 455-468.

Chapagain, A.K., Hoekstra, A.Y., Savenije, H.H.G. and Gautam, R. (2006b) The water footprint of cotton consumption: An assessment of the impact of worldwide consumption of cotton products on the water resources in the cotton producing countries, Ecological Economics 60(1): 186-203.

Chapagain, A.K. and Hoekstra, A.Y. (2008) The global component of freshwater demand and supply: An assessment of virtual water flows between nations as a result of trade in agricultural and industrial products, Water International 33(1): 19-32.

Charnovitz, S. (2002) The law of environmental "PPMs" in the WTO: Debunking the myth of illegality, The Yale Journal of International Law 27(1): 59-110.

De Fraiture, C., Cai, X., Amarasinghe, U., Rosegrant, M. and Molden, D. (2004) Does international cereal trade save water? The impact of virtual water trade on global water use, Comprehensive Assessment Research Report 4, IWMI, Colombo, Sri Lanka.

Gleick, P.H. (1999) The human right to water, Water Policy 1(5): 487-503.

Gleick, P.H. (2004) The myth and reality of bottled water, In: Gleick, P.H. (ed.) The world's water 2004-2005, The biennial report on freshwater resources, Island Press, Washington, D.C., USA, pp.17-43.

Gleick, P.H., Wolff, G., Chalecki, E.L. and Reyes, R. (2002) Globalization and international trade of water, In: Gleick, P.H. et al. (ed.) The world's water 2002-2003, The biennial report on freshwater resources, Island Press, Washington, D.C., USA, pp.33-56.

Greenaway, F., Hassan, R. and Reed, G.V. (1994) An empirical-analysis of comparative advantage in Egyptian agriculture, Applied Economics 26(6): 649-657.

Grote, U., Craswell, E., and Vlek, P. (2005) Nutrient flows in international trade: Ecology and policy issues, Environmental Science and Policy 8: 439-451.

GWP (2000) Integrated water resources management, TAC Background Paper No.4, Global Water Partnership, Stockholm, Sweden.

Haddadin, M.J. (2003) Exogenous water: A conduit to globalization of water resources, in: A.Y. Hoekstra, Virtual water trade: Proceedings of the International Expert Meeting on Virtual Water Trade, Value of Water Research Report Series No. 12, UNESCO-IHE, Delft, pp. 159-169.

Hoekstra, A.Y. (ed.) (2003) Virtual water trade: Proceedings of the International Expert Meeting on Virtual Water Trade, Delft, The Netherlands, 12-13 December 2002, Value of Water Research Report Series No.12, UNESCO-IHE, Delft, The Netherlands.

Hoekstra, A.Y. (2006) The global dimension of water governance: Nine reasons for global arrangements in order to cope with local water problems, Value of Water Research Report Series No.20, UNESCO-IHE, Delft, The Netherlands. 
Hoekstra, A.Y. and Chapagain, A.K. (2007) Water footprints of nations: Water use by people as a function of their consumption pattern, Water Resources Management 21(1): 35-48.

Hoekstra, A.Y. and Chapagain, A.K. (2008) Globalization of water: Sharing the planet's freshwater resources, Blackwell Publishing, Oxford, UK.

Hoekstra, A.Y., and Hung, P.Q. (2005) Globalisation of water resources: International virtual water flows in relation to crop trade, Global Environmental Change 15(1): 45-56.

ICWE (1992) The Dublin statement on water and sustainable development, International Conference on Water and the Environment, Dublin.

ITC (2004) PC-TAS version 1997-2001, Harmonized System, CD-ROM, International Trade Centre, Geneva, Switzerland.

Liao, Y., De Fraiture, C. and Giordano, M. (2008) Global trade and water: lessons from China and the WTO, Global Governance 14: 503-521.

Ma, J., Hoekstra, A.Y., Wang, H., Chapagain, A.K. and Wang, D. (2006) Virtual versus real water transfers within China, Philosophical Transactions of the Royal Society of London B 361(1469): 835-842.

Maclean, J.L., Dawe, D.C., Hardy, B. and Hettel, G.P. (2002) Rice almanac: Source book for the most important economic activity on earth, International Rice Research Institute, Los Baños, Philippines.

McIsaac, G.F., David, M.B., Gertner, G.Z. and Goolsby, D.A. (2001) Eutrophication: Nitrate flux in the Mississippi river, Nature 414(6860): 166-167.

Mehta, L. and La Cour Madsen, B. (2005) Is the WTO after your water? The General Agreement on Trade in Services (GATS) and poor people's right to water, Natural Resources Forum 29: 154-164.

Meybeck, M. (2004) The global change of continental aquatic systems: dominant impacts of human activities, Water Science and Technology 49(7): 73-83.

Neumayer, E. (2004) The WTO and the environment: Its past record is better than critics believe, but the future outlook is bleak, Global Environmental Politics 4(3): 1-8.

Nriagu, J.O. and Pacyna, J.M. (1988) Quantitative assessment of worldwide contamination of air, water and soils by trace metals, Nature 333: 134-139.

Oki, T. and S. Kanae, (2004), Virtual water trade and world water resources, Water Science and Technology 49(7): 203-209.

Ramirez-Vallejo, J. and P. Rogers (2004) Virtual water flows and trade liberalization, Water Science and Technology 49(7): 25-32.

Ricardo, D. ([1817] 2006) On the principles of political economy and taxation, Cosimo, New York, USA.

Rogers, P., Bhatia, R., and Huber, A. (1998) Water as a social and economic good: How to put the principle into practice, TAC Background Papers No. 2, Global Water Partnership, Stockholm, Sweden.

Sanchez, P.A. (2002) Soil fertility and hunger in Africa, Science 295(5562): 2019-2020.

Savenije, H.H.G. (2002) Why water is not an ordinary economic good, or why the girl is special, Physics and Chemistry of the Earth 27:741-744.

Stocking, M.A. (2003) Tropical soils and food security: The next 50 years, Science 302(5649): 1356-1359. 
Tilman, D., Fargione, J., Wolff, B., D'Antonio, C., Dobson, A., Howarth, R., Schindler, D., Schlesinger, W.H., Simberloff, D. and Swackhamer, D. (2001) Forecasting agriculturally driven global environmental change, Science 292(5515): 281-284.

Verkerk, M.P., Hoekstra, A.Y. and Gerbens-Leenes, P.W. (2008) Global water governance: Conceptual design of global institutional arrangements, Value of Water Research Report Series No.26, UNESCO-IHE, Delft, The Netherlands.

Verma, S., Kampman, D.A., Van der Zaag, P. and Hoekstra, A.Y. (2009) Going against the flow: A critical analysis of inter-state virtual water trade in the context of India's National River Linking Programme, Physics and Chemistry of the Earth 34: 261-269.

Wichelns, D. (2001) The role of 'virtual water' in efforts to achieve food security and other national goals, with an example from Egypt, Agricultural Water Management 49(2): 131-151.

Wichelns, D. (2004) The policy relevance of virtual water can be enhanced by considering comparative advantages, Agricultural Water Management 66(1): 49-63.

WTO (2008) Understanding the WTO, Fourth edition, World Trade Organization, Geneva, Switzerland.

Yang, H., Reichert, P., Abbaspour, K.C., and Zehnder, A.J.B. (2003) 'A water resources threshold and its implications for food security' Environmental Science and Technology 37:3048-3054.

Yang, H., Wang, L., Abbaspour, K.C. and Zehnder, A.J.B. (2006) Virtual water trade: an assessment of water use efficiency in the international food trade, Hydrology and Earth System Sciences 10(3): 443-454.

Yang, H., Wang, L., and Zehnder, A. (2007) Water scarcity and food trade in the Southern and Eastern Mediterranean countries, Food Policy 32:585-605. 